\title{
Microwave assisted N-chlorination of secondary amides
}

\author{
Alan R. Katritzky*, Suman Majumder, and Ritu Jain \\ Center for Heterocyclic Compounds, Department of Chemistry, University of Florida, \\ Gainesville, Florida 32611- 7200, USA \\ E-mail: katritzky@chem.ufl.edu
}

Dedicated to Professor Henry J. Shine on his $80^{\text {th }}$ Anniversary

(received 21 Aug 03; accepted 30 Sept 03; published on the web 10 Oct 03)

\begin{abstract}
Acyclic (1a-c), and cyclic (4a-f) secondary amides are $\mathrm{N}$-chlorinated by $N$-chlorobenzotriazole under 15-20 minutes of microwave heating to give the corresponding $N$-chloro secondary amides (3a-c, 5a-f) in yields of 50-80\%.
\end{abstract}

Keywords: Microwave, N-chloro secondary amides

\section{Introduction}

$N$-Haloamides are used as photoinitiators for radical polymerization ${ }^{1}$ and in room temperature vulcanization for the preparation of adhesives, caulks and sealants. ${ }^{2}$ They are also versatile reagents in organic synthesis as oxidizing agents in aqueous and non aqueous media. ${ }^{3}$ Photolysis of $\mathrm{N}$-haloamides gives amidyl radicals and halogen atom intermediates. ${ }^{4-9}$ The amidyl radicals so produced undergo efficient intramolecular addition to olefinic bonds. ${ }^{5}$ 9-12 Olefinic amidyl radicals can ring-close to lactams or $\mathrm{N}$-heterocyclic amides. ${ }^{13} \mathrm{~N}$-chloroamides undergo the Hofmann reaction $^{14}$ and Orton rearrangements. ${ }^{15,16}$

Many literature methods are reported for the synthesis of primary N-chloroamides. ${ }^{17}$ Routes to synthesize secondary $\mathrm{N}$-chloroamides include chlorination of secondary amides with $\mathrm{NaCl}$ in the presence of oxone, ${ }^{18}$ t-butyl hypochlorite, ${ }^{19-21}$ sodium hypochlorite, ${ }^{22-24}$ and $N$ chlorosuccinimide. ${ }^{25}$ These methods for the synthesis of secondary N-chloroamides have their own limitations. $t$-Butyl hypochlorite is unstable and hazardous, ${ }^{18}$ reaction with $\mathrm{NaCl}$ in presence of oxone can require 2-5 hours. ${ }^{18}$

Microwave heating has emerged as an environmental friendly technique to accelerate a variety of chemical reactions. ${ }^{26,27}$ Automated and focused microwave flash heating has recently been demonstrated to improve the preparative efficacy and to dramatically reduce reaction times for many different types of organic trasformations. ${ }^{26,} 28$ We now report that by applying 
microwave heating, the N-chlorination of cyclic and acyclic secondary amides can be done in 15-20 minutes using $N$-chlorobenzotriazole as the chlorinating agent.

\section{Results and Discussion}

Optimization of the reaction conditions was carried out for the chlorination of secondary amides and different combinations of temperature, time and irradiation power were studied for $\mathrm{N}$ methylbenzamide (1a) in order to achieve the maximum chemical yield at the lowest reaction temperature. Microwave irradiation of $\mathbf{1 a}$ for more than 20 minutes caused decomposition. The power and the temperature of reaction for the different compounds were set according to the melting points of the starting materials. Maximum yields were observed when the power is $80-$ $90 \mathrm{~W}$. On increasing the power above $90 \mathrm{~W}$, decomposition took place. The completion of reaction was checked by disappearance of the secondary amide in TLC. Scheme 1 shows the time and temperature used for the preparation of secondary $\mathrm{N}$-chloroamides.

The reaction of $\mathrm{N}$-methylbenzamide (1a) with $\mathrm{N}$-chlorobenzotriazole was attempted in the absence of microwave irradiation. After refluxing $\mathrm{N}$-methylbenzamide (1a) with $\mathrm{N}$ chlorobenzotriazole in acetonitrile for $16 \mathrm{~h}$, a yield of $60 \%$ of the product was obtained. In contrast, the reaction was completed (as monitored by TLC) in 20 minutes in the case of microwave heating.

Literature reports have characterized secondary N-chloroamides by IR, UV and NMR spectroscopy, ${ }^{18}$ chlorine estimation, ${ }^{29}$ iodometric assay ${ }^{30}$ and $\mathrm{CHN}$ analysis. ${ }^{30,31}$ The NMR data showed the absence of $\mathrm{N}-\mathrm{H}$ protons. In ${ }^{1} \mathrm{H}$ and ${ }^{13} \mathrm{C} \mathrm{NMR}$, the $\mathrm{N}(\mathrm{Cl})-\mathrm{CH}_{2}$ protons showed a downfield shift as compared to the $\mathrm{NH}-\mathrm{CH}_{2}$ protons. In our experiments, the completion of the reaction was confirmed by the disappearance of the amide on TLC followed by the disappearance of NH proton in NMR, which was further confirmed by CHN analysis. The NMR data of 1-chloro-2-azepanone was in close agreement with the literature data. ${ }^{18}$

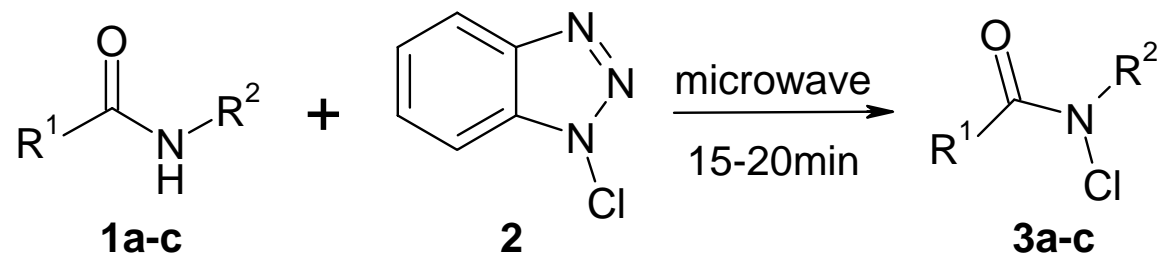

Scheme 1. Synthesis of secondary N-chloroamides.

Table1. Microwave conditions and yields for the preparation of secondary N-chloroamides

\begin{tabular}{|c|c|c|c|c|c|c|c|}
\hline & $\mathrm{R}^{1}$ & $\mathrm{R}^{2}$ & $\begin{array}{l}\text { Time } \\
(\mathrm{min})\end{array}$ & $\begin{array}{c}\text { Temp } \\
\left({ }^{\circ} \mathrm{C}\right)\end{array}$ & $\begin{array}{c}\text { Power } \\
\text { (Watts) }\end{array}$ & $\begin{array}{l}\text { Yield } \\
(\%)\end{array}$ & Lit. yield (\%) \\
\hline 3a & $-\mathrm{C}_{6} \mathrm{H}_{5}$ & $-\mathrm{CH}_{3}$ & 15 & 65 & 80 & 80 & $85^{32}$ \\
\hline
\end{tabular}




\begin{tabular}{cccccccc}
\hline & & & & & & & $98^{33}$ \\
3b & $-\mathrm{C}_{6} \mathrm{H}_{5}$ & $-\mathrm{CH}_{2} \mathrm{C}_{6} \mathrm{H}_{5}$ & 15 & 65 & 90 & 82 & - \\
3c & $-\mathrm{CH}_{3}$ & $-\mathrm{C}_{3} \mathrm{H}_{7}$ & 20 & 50 & 80 & 87 & $71^{34}$ \\
\hline
\end{tabular}

The synthesis of N-chloro-N-methylbenzamide was reported with $t$-butylhypochlorite in high yields but requires $12 \mathrm{~h}$; our reaction conditions are mild and the reaction can be finished in 15 minutes time. The same methodology converted cyclic secondary amides into the corresponding $\mathrm{N}$-chloro amides in good to excellent yields in 15 minutes (Scheme 2). The benzotriazole formed in the reactions was removed by washing with a saturated solution of sodium carbonate to give pure products.

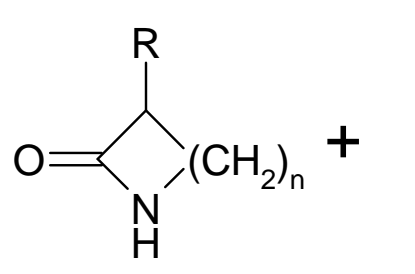

4a-f<smiles>ClC1CCCCC1</smiles>

2<smiles>[R]C1CN(Cl)C1=O</smiles>

5a-f

Scheme 2. Synthesis of N-chloro cyclic secondary amides.

Table2. Microwave conditions and yields for the preparation of $\mathrm{N}$-chloro cyclic secondary amides

\begin{tabular}{cccccccc}
\hline & $\mathrm{n}$ & $\mathrm{R}$ & $\begin{array}{c}\text { Time } \\
(\mathrm{min})\end{array}$ & $\begin{array}{c}\text { Temp } \\
\left({ }^{\circ} \mathrm{C}\right)\end{array}$ & $\begin{array}{c}\text { Power } \\
(\text { Watts })\end{array}$ & $\begin{array}{c}\text { Yield } \\
(\%)\end{array}$ & Lit. yield \\
\hline $\mathbf{5 a}$ & 1 & $\mathrm{H}$ & 15 & 60 & 80 & 80 & \\
$\mathbf{5 b}$ & 2 & $\mathrm{Me}$ & 15 & 60 & 80 & 56 & \\
$\mathbf{5 c}$ & 3 & $\mathrm{H}$ & 15 & 60 & 80 & 55 & $64^{9}$ \\
$\mathbf{5 d}$ & 4 & $\mathrm{H}$ & 15 & 60 & 80 & 65 & $73.5^{31}$ \\
& & & & & & & $43^{35}$ \\
$\mathbf{5 e}$ & 6 & $\mathrm{H}$ & 15 & 60 & 80 & 81 & $*$ \\
$\mathbf{5 f}$ & 10 & $\mathrm{H}$ & 15 & 60 & 80 & 85 & $*$ \\
\hline
\end{tabular}

* The yields of $\mathbf{5 e}$ and $\mathbf{5 f}$ are not reported in the literature.

Reported methods for the synthesis of $\mathbf{5 d}$ and 5e comprises exposing a solution of lactam in an organic solvent to chlorine gas in the presence of UV light ${ }^{35}$ which also promotes polymerization to some extent. However, in our reactions we didn't observe any polymerization and the reagents used are non-hazardous with minimal solvent and short reaction time. 
To summarize, this paper provides an effective method for the preparation of $N$-chloro secondary amides: microwave irradiation leads to reaction rate enhancement, improved yields and safe conditions.

\section{Experimental Section}

General Procedures. Melting points are uncorrected. All the reactions under microwave irradiation were conducted in heavy-walled Pyrex tubes sealed with aluminum crimp caps fitted with a silicon septum under controlled conditions in a safe and reproducible procedure. Single mode microwave irradiation was used at a fixed temperature, pressure and irradiation power during the reaction time by an automatic power control. Microwave heating was carried out with a single mode cavity Discover ${ }^{\circledR}$ microwave synthesizer (CEM Corp., NC), producing continuous irradiation at $2455 \mathrm{MHz} .{ }^{1} \mathrm{H}$ NMR (300 MHz) and ${ }^{13} \mathrm{C}$ NMR (75 MHz) spectra were recorded in $\mathrm{CDCl}_{3}$ (with TMS for ${ }^{1} \mathrm{H}$ and chloroform- $d$ for ${ }^{13} \mathrm{C}$ as the internal reference) unless specified otherwise.

Materials. 1-Chloro- $1 H$-benzotriazole (2) was synthesized according to the previously published procedure: ${ }^{36}$ white crystals (94\%), mp $104-106^{\circ} \mathrm{C}\left(103-105^{\circ} \mathrm{C}\right)^{36}$.

\section{General procedure for the chlorination of secondary amides 1a-c and 4a-f using microwave irradiation}

A dried heavy-walled Pyrex tube containing a small stirring bar was charged with secondary amide 1 (2.0 mmol) and $N$-chlorobenzotriazole (2) (2.0 mmol). The tube containing the reaction mixture was sealed with an aluminum crimp cap fitted with a silicon septum and then it was exposed to microwave irradiation (80-90 W) for $15-30 \mathrm{~min}$ at a temperature of $60-100{ }^{\circ} \mathrm{C}$. The buildup of pressure in the closed reaction vessel was carefully monitored and was found to be typically in the range 4-10 psi. After the irradiation, the reaction tube was cooled with highpressure air through an inbuilt system in the instrument until the temperature had fallen below $40{ }^{\circ} \mathrm{C}$ (ca. $2 \mathrm{~min}$ ). The crude reaction mixture was checked by TLC for the disappearance of the amide. The reaction mixture was washed successively with saturated solution of aqueous sodium carbonate to remove benzotriazole. The solvent was evaporated to give the pure product. The same procedure was used for the synthesis of $\mathbf{5 a - f}$ using $\mathbf{4 a - f}$ as the starting materials respectively. Analytically pure samples of compounds 5e-f were prepared by column chromatography.

$\boldsymbol{N}$-Chloro- $\boldsymbol{N}$-methylbenzamide (3a). ${ }^{29,}$ 32, 34, 37 Yellow oil; yield 80\%; ${ }^{1} \mathrm{H}$ NMR $\delta 3.44$ (s, 3H), 7.40-7.48 (m, 3H), 7.54-7.57 (m, 2H); ${ }^{13} \mathrm{C}$ NMR $\delta 43.6,127.9,128.3,130.9,133.3,171.7$. Anal. Calcd for $\mathrm{C}_{8} \mathrm{H}_{8} \mathrm{ClNO}$ : N, 8.26. Found: N, 8.64.

$\boldsymbol{N}$-Benzyl- $\boldsymbol{N}$-chlorobenzamide (3b). White plates; yield 82\%; mp $109-110{ }^{\circ} \mathrm{C}$; ${ }^{1} \mathrm{H}$ NMR $\delta 4.89$ (s, 2H), 7.29-7.46 (m, 8H), 7.57 (d, $J=6.9 \mathrm{~Hz}, 2 \mathrm{H}) ;{ }^{13} \mathrm{C}$ NMR $\delta$ 58.0, 127.6, 127.7, 128.0, 
128.3, 128.6, 130.8, 133.3, 135.0, 171.1. Anal. Calcd for $\mathrm{C}_{14} \mathrm{H}_{12} \mathrm{ClNO}$ : , 68.44; H, 4.92; N, 5.70. Found: C, 68.63; H, 4.89; N, 5.98.

$\boldsymbol{N}$-Chloro- $\boldsymbol{N}$-propylacetamide (3c). ${ }^{32}$ Yellow oil; yield 87\%; ${ }^{1} \mathrm{H}$ NMR $\delta 0.88$ (t, $J=7.4 \mathrm{~Hz}$, 3H), 1.61-1.73 (m, 2H), 2.20 (s, 3H), 3.62 (t, $J=7.0 \mathrm{~Hz}, 2 \mathrm{H}) ;{ }^{13} \mathrm{C}$ NMR $\left(80{ }^{\circ} \mathrm{C}\right) \delta 10.4,20.4$, 21.5, 53.9, 171.3. Anal. Calcd for $\mathrm{C}_{5} \mathrm{H}_{10} \mathrm{ClNO}$ : N, 10.33. Found: $\mathrm{N}, 10.12$.

1-Chloro-2-azetanone (5a). Yellow oil; yield 80\%; ${ }^{1} \mathrm{H}$ NMR $\delta 3.19$ (t, $\left.J=4.4 \mathrm{~Hz}, 2 \mathrm{H}\right), 3.61$ (t, $J=4.4 \mathrm{~Hz}, 2 \mathrm{H}) ;{ }^{13} \mathrm{C}$ NMR $\delta$ 38.4, 46.9, 166.9. Anal. Calcd for $\mathrm{C}_{3} \mathrm{H}_{4} \mathrm{ClNO}$ : C, 34.15; H, 3.82; N, 13.27. Found: C, 34.45; H, 3.48; N, 12.85 .

1-Chloro-3-methyl-2-pyrrolidinone (5b). Yellow oil; yield 56\%; ${ }^{1} \mathrm{H}$ NMR $\delta 1.23-1.27$ (m, 3H), 1.78-1.90 (m, 1H), 2.36-2.54 (m, 2H), 3.53-3.58 (m, 2H); ${ }^{13} \mathrm{C}$ NMR $\delta 16.3,27.0,34.0$, 50.3, 175.2. Anal. Calcd for $\mathrm{C}_{5} \mathrm{H}_{8} \mathrm{ClNO}$ : N, 10.49. Found: N, 10.18 .

1-Chlorotetrahydro-2(1H)-pyridinone (5c). ${ }^{9}$ Yellow oil; yield 55\%; ${ }^{1} \mathrm{H}$ NMR $\delta$ 1.84-1.92 (m, 2H), 1.95-2.03 (m, 2H), 2.59 (t, $J=6.6 \mathrm{~Hz}, 2 \mathrm{H}), 3.75$ (t, $J=6.0 \mathrm{~Hz}, 2 \mathrm{H}) ;{ }^{13} \mathrm{C}$ NMR $\delta 21.2,24.9$, 33.9, 57.2, 167.5. Anal. Calcd for $\mathrm{C}_{5} \mathrm{H}_{8} \mathrm{ClNO}$ : C, 44.96; H, 6.04; N, 10.49. Found: C, 45.17; H, 6.36; N, 10.80 .

1-Chloro-2-azepanone (5d). ${ }^{18,}$ 30, 31, 35 , Yellow oil; yield 65\%; ${ }^{1} \mathrm{H}$ NMR $\delta$ 1.66-1.85 (m, 6H), 2.63-2.68 (m, 2H), 3.86 (br s, 2H); ${ }^{13} \mathrm{C}$ NMR $\delta$ 22.5, 26.7, 28.8, 35.6, 57.8, 173.0. Anal. Calcd for $\mathrm{C}_{6} \mathrm{H}_{10} \mathrm{ClNO}$ : C, 48.82; H, 6.83; N, 9.49. Found: C, 48.63; H, 6.91; N, 9.73.

1-Chloro-azonan-2-one (5e). ${ }^{30}$ Yellow oil; yield 81\%; ${ }^{1} \mathrm{H}$ NMR $\delta 1.32-1.42$ (m, 2H), 1.49-1.57 (m, 2H), 1.63-1.70 (m, 2H), 1.82-1.89 (m, 4H), 2.62-2.66 (m, 2H), $3.91(\mathrm{t}, J=5.7 \mathrm{~Hz}, 2 \mathrm{H}) ;{ }^{13} \mathrm{C}$ NMR $\delta$ 19.6, 24.6, 26.2, 26.5, 28.0, 35.9, 54.3, 173.4. Anal. Calcd for $\mathrm{C}_{8} \mathrm{H}_{14} \mathrm{ClNO}$ : C, 54.70; $\mathrm{H}$, 8.03; N, 7.97. Found: C, 54.68; H, 8.03; N, 7.97.

1-Chloro-azacyclotridecan-2-one $\quad(5 f) .{ }^{33}$ Colorless oil; yield $85 \%$; ${ }^{1} \mathrm{H} \quad \mathrm{NMR}\left(80 \quad{ }^{\circ} \mathrm{C}\right)$ $\delta$ 1.28-1.37 (m, 12H), 1.39-1.46 (m, 2H), 1.67-1.81 (m, 4H), 2.56 (br s, 2H), 3.80 (br s, 2H),

${ }^{13} \mathrm{C}$ NMR $\left(80{ }^{\circ} \mathrm{C}\right) \delta 24.1,24.2,25.2$, 25.3, 25.7, 26.2, 26.3, 26.6, 26.7, 33.2, 51.6, 167.3. Anal. Calcd for $\mathrm{C}_{12} \mathrm{H}_{22} \mathrm{ClNO}$ : C, 62.19; H, 9.57; N, 6.04. Found: C, 62.47; H, 9.83; N, 6.29.

\section{References}

1. Liliana, G.; Paolo, C.; Giamperio, M.; Attilio, C. EP 458,197 1991; Chem. Abstr. 1992, 116, 107012w.

2. Cantor, S. E. Adhes. Age 1974, 17, 17; Chem. Abstr. 1974, 81, 122012y.

3. Gowda, B. T.; Weiss, A. Z. Naturforsch. A: Phys. Sci. 1994, 49, 695; Chem. Abstr. 1994, 121, 204710h.

4. Glover, S. A.; Goosen, A.; McCleland, C. W.; Schoonraad, J. L. J. Chem. Soc., Perkin Trans. II 1986, 645.

5. Lessard, J.; Mondon, M.; Touchard, D. Can. J. Chem. 1981, 59, 431.

6. Mackiewicz, P.; Furstoss, R. Tetrahedron 1978, 34, 3241.

7. Goosen, A.; McCleland, C. W.; Merrifield, A. J. J. Chem. Soc., Perkin Trans. I 1992, 627. 
8. Neale, R. S. Synthesis 1971, 1, 1.

9. Phan, X. T.; Shannon, P. J. J. Org. Chem. 1983, 48, 5164.

10. Chow, Y. L.; Perry, R. A. Tetrahedron Lett. 1972, 531.

11. Mackiewicz, P.; Furstoss, R.; Waegell, B. J. Org. Chem. 1978, 43, 3746.

12. Touchard, D.; Lessard, J. Tetrahedron Lett. 1971, 4425.

13. Kuehne, M. E.; Horne, D. A. J. Org. Chem. 1975, 40, 1287.

14. Magnien, E.; Baltzly, R. J. Org. Chem. 1958, 23, 2029.

15. Barton, D.; Ollis, W. D. In Comprehensive Organic Chemistry; Sutherland, I. O., Ed.; Pergamon Press: New York, 1979; Vol. 2, pp 1030.

16. Bieron, J. F.; Dinan, F. J. In The Chemistry of Amides; Zabicky, J., Ed.; Interscience: New York, 1970; p 245.

17. Connell, R. D. In Comprehensive Organic Functional Group Transformations; Moody, C. J., Ed.; Pergamon Press: 1995; Vol. 5, p 309.

18. Curini, M.; Epifano, F.; Marcotullio, M. C.; Rosati, O.; Tsadjout, A. Synlett 2000, 6, 813.

19. Johnson, R. A.; Greene, F. D. J. Org. Chem. 1975, 40, 2186.

20. Duhamel, L.; Plé, G.; Angibaud, P.; Desmurs, J. R. Syn. Comm. 1993, 23, 2423.

21. Altenkirk, B.; Israelstam, S. S. J. Org. Chem. 1962, 27, 4532.

22. Lessard, J.; Cote, R. J. Org. Chem. 1978, 43, 3750.

23. Underwood, G. R.; Dietze, P. E. J. Org. Chem. 1984, 49, 5225.

24. Katritzky, A. R.; Khan, G. R.; Leahy, D. E.; de Rosa, M. J. Org. Chem. 1984, 49, 4784.

25. Back, T. G.; Lai, E. K. Y.; Morzycki, J. W. Heterocycles 1991, 32, 481.

26. Hayes, B. L. In Microwave Synthesis: Chemistry at the Speed of Light; CEM Publishing: Matthews, NC, 2002.

27. Caddick, S. Tetrahedron 1995, 51, 10403.

28. Lidström, P.; Tierney, J.; Wathey, B.; Westman, J. Tetrahedron 2001, 57, 9225.

29. Hardy, F. E.; Robson, P. J. Chem. Soc. 1967, 1151.

30. Edwards, O. E.; Paton, J. M.; Benn, M. H.; Mitchell, R. E.; Watanatada, C.; Vohra, K. N. Can. J. Chem. 1971, 49, 1648.

31. Beyer, H.; Korösi, J. Chem. Ber. 1961, 94, 480.

32. Mitin, Yu. V.; Vlasov, G. P. Probl. Organ. Sinteza 1965, 297; Chem. Abstr. 1966, 64, 59638.

33. Phan, X. T.; Shannon, P. J. US 4,492,619 1985; Chem. Abstr. 1985, 102, 185645e.

34. Burstall, M. L.; Gibson, M. S.; Greig, J. S.; McGhee, B.; Stewart, D. G. J. Chem. Soc. 1960, 3717.

35. Choi, S. K. US 3,945,897, 1976; Chem. Abstr. 1976, 85, 6397m.

36. Hughes, T. V.; Hammond, S. D.; Cava, M. P. J. Org. Chem. 1988, 63, 401.

37. Lengyel, I.; Cesare, V.; Stephani, R. Synth. Comm. 1998, 28, 1891. 